\title{
State tax control strategies: Theoretical aspects
}

\author{
Estrategias de control tributario del estado: aspectos teóricos
}

\author{
Gulnar Aytkhozhina* and Alexander Miller
}

Dostoevsky Omsk State University, Russian Federation

Received 11 september 2017; accepted 13 december 2017

Available online 19 march 2018

\begin{abstract}
The aim of this article is the justification for the benefits of tax control in modern conditions of society development, based simultaneously on coercion, service, credibility and partnership. The study includes econometric estimates based on empirical data. An institutional and delictual approach is used along with methods of data processing and analysis. The source of data was the survey results of 1600 respondents from 153 municipalities of Russia as well as Russia State statistical data authorities and the World Bank data. This article considers a theoretical basis for existent strategies of tax control, tax compliance. The specifics and benefits for the integrated strategy, moral factors involved, are being revealed. It is focused on state tax risks management based on partnership relations. The results have shown a close relationship between tax morale and shadow economy level as an indicator for tax compliance (based on correlation, regression), which is confirmed by priority and potential of the proposed strategy. The main tools for the forming of partnership relationships in tax matters are proposed. The efficiency of this strategy is shown by a comparison of gains and losses.
\end{abstract}

JEL classification: E62; H26; Z10

Keywords: Tax control; Tax compliance; Tax control strategies; Tax behaviour; Tax moral.

*Corresponding author

E-mail address: ags8@mail.ru (G. Aytkhozhina)

Peer review under the responsibility of Universidad Nacional Autónoma de México. 


\section{Resumen}

El objetivo de este artículo es la justificación de los beneficios del control tributario en las modernas condiciones del desarrollo de la sociedad, basándose simultáneamente en la coerción, el servicio, la credibilidad y la asociación. El estudio incluye estimados econométricos que se basan en datos empíricos. Se utiliza un enfoque institucional y delictual junto con métodos de procesamiento y análisis de datos. La fuente de los datos fueron los resultados de la encuesta a 1600 participantes de 153 municipalidades de Rusia, así como a las autoridades de datos estadísticos del Estado Ruso y datos del Banco Mundial. Este artículo considera una base teórica para las actuales estrategias de control tributario y cumplimiento tributario. Se revelan los detalles y beneficios de la estrategia integrada, incluyendo los factores morales. Se centra en la administración por el estado de los riesgos tributarios con base en las relaciones entre sociedades. Los resultados demuestran una cercana relación entre moral tributaria y el nivel de la economía informal como indicador para el cumplimiento tributario (con base en correlación, regresión), que se confirma con la prioridad y potencial de la estrategia propuesta. Se proponen las principales herramientas para la formación de relaciones entre sociedades para asuntos tributarios. La eficiencia de esta estrategia se demuestra con la comparación de pérdidas y ganancias.

Códigos JEL: E62; H26; Z10

Palabras clave: Control tributario; El cumplimiento de las obligaciones fiscales; Estrategias de control tributario; Comportamiento tributario; Moral fiscal.

\section{Introduction}

Most of the countries including Russia are characterized by serious problems in tax relations, which affect economy and social development of the state due to low level of tax compliance. Tax evasion is widely spread both in space and time. It is confirmed by the scale of shadow economy. Thus, Eurostat assesses the size of the hidden part of economy in 2013 in 11 countries of Europe at the level of more than $15 \%$ with a maximum value of $27 \%$ in Estonia (Schneider, 2014). Russian statistical agencies are very optimistic concerning the informal sector in the country economy - 14\% versus the World Bank assessing it at the level of $39 \%$ (Rosstat; World Bank).

High level of a hidden economic activity leads to not only the breach of justice principles in taxation but also to outlier government revenues and consequently limited resources for social goals and the absence of conditions of fair competition. In the meantime, it is reflected by the lack of efficiency of fiscal control.

In modern conditions of economy globalization, democratization and information development of society, business models and capital flows transformation, new requirements, different form the previous ones, are placed on taxation state control. The above factors influence the complexity of the tasks facing tax authorities. This is stated in the reports of the Organization for the Economic Cooperation and Development (OECD, 2015; OECD, 2017) and by individual experts (Maiburov \& Sokolovskaya, 2012).

State fiscal control (fiscal, imperative) is contradictory by its nature representing a social mechanism of influence of one group of people on other persons' behaviour, forcing the latter to the given type of behaviour (Dementev, 2009, p. 19). The given mechanism has its purposes 
of tax relations regulation, organization structure and its form. It is up to them to define the control strategy and necessitate, on one hand, the efficiency of control; on the other hand, state expenditure for tax compliance. The high cost of tax compliance is an international problem (OECD, 2015). States face costs to gather information and process data, to identify and assess risks, to prevent violations, to exercise direct control and costs of the penalty system, in other words, transaction costs (Kapelyushnikov, 1994). However, the level of tax compliance still contains quite a significant potential.

Fundamental improvement of the situation requires a radical change in tax administration of control strategy, the most effective under proper conditions of development of the state, aimed at multiplicative result: economic growth, social stability, increasing resilience of societal development.

This article defines the advantages of the integrated strategy of tax control which provides the improvement of quality of tax relations whilst reducing state expenditure (transaction costs) for control and the prospects of the proposed strategy in Tax Administration of Russia are being assessed.

\section{Literature review}

So far, various theories of tax compliance have been widely developed, forming the theoretic basis for the tax control strategies, namely, the theories: of deterrence, behaviorism and the signal one (Manhire, 2016).

One of the first such theories, the theory of deterrence, was developed by American scientists M. Allingham and A. Sandmo in 1972 (Allingham \& Sandmo, 1972). It was built upon the theory of the economics of crime by G. Becker, Nobel Laureate, linking a rational choice of the individual with the comparison of expected gains and losses (expenses) (Becker, 1968). The starting position of the deterrence theory is causation of economic behaviour of an individual by the rationality of his choice, aimed at maximizing the benefits. According to this assumption, a reasonable person will assess the advantages of successful tax evasion based on the knowledge of tax rate, probability of Tax Audit and the amount of fines. Rational choice is carried out between two options: 1) to declare completely the actual revenue (W); 2) to show a lower actual revenue $(\mathrm{X})$. The second option can bring benefits in case of not discovering the understated profits by controlling authorities. That is, expected benefits (the usefulness - U) are directly dependent on the income and are inversely related to the probability of the audit and the amount of fines. This correlation was found by M. Allingham and A. Sandmo in the model of expected usefulness, taking into account the following variables (economic parameters); tax rate $(\theta)$, probability of the audit $(\mathrm{p})$, amount of fines $(\pi)$, as follows (Allingham \& Sandmo, 1972):

$$
\mathrm{E}[\mathrm{U}]=(1-\mathrm{p}) \mathrm{U}(\mathrm{W}-\theta \mathrm{X})+\mathrm{pU}(\mathrm{W}-\theta \mathrm{X}-\pi(\mathrm{W}-\mathrm{X}))
$$

According to the developed static model of the taxpayer's choice, if expected benefit is a positive figure, the taxpayer will choose tax evasion. However, empirical data contradict this theory, which is explained by the model specificity, expressed in limited factors consideration of tax behaviour (only economic), in considerable simplification of real conditions (rejection of value judgements of audit probability, the amount of fines of formal rules are ignored). At the 
same time, the built model is recognized as the classic one and has become both the base and incentive for further scientific work in this subject area.

It is the theory of deterrence that is the basic strategy of tax control known as "Coercive strategy". In this strategy, the main motivational instrument is economic deterrence from tax evasion. Focusing on the rational choice of economic actors, the comparison of gains and losses expected by them by tax evasion, the coercive strategy is realized through the system of formal motivations for economic actors (formal rules addresses): high level of the audit probability (total control), high level of responsibility (higher fines, seizure of property, criminal liability). Coercive strategy implies the deterrence of non-compliance with tax regulations by economic actors by coercive and punitive measures. The whole emphasis on economic factors of tax behaviour necessitates the limits (limitation) of the coercive strategy.

This lack can be neutralized by strategies based on the behaviorism theory. The basis for this theory is recognition of incomplete rationality of economic actors as the result of influence of many factors and constraints: social, psychological, neurological and others (Bruno \& Frey, 1997; Devos, 2014; Hayashi, 2012; Kirchler, \& Braithwaite, 2007). There is no rational person in real conditions. Mental, intellectual, cultural and other characteristics of people don't allow them to rationalize completely the choice in the tax compliance. Behaviorism, admitting the variety of behavioral response for taxation, includes non-economic factors of tax compliance, taking into consideration a number of variables from psychology, sociology, political science. In particular, moral values, education, culture, perception of fairness of taxation, confidence in the state and tax authorities. Alternatively to the theory of economic deterrence, behavioral concepts explain the tax compliance of social, moral, culture constraints, confidence in the authorities etc.

The listed factors add to the public policy tool in the field of the tax legislation compliance except for coercive measures. Complex combination of tax compliance determinants was presented by V. Braithwaite (2003) in one model. Five key components (business, industry, sociological, economic and psychological) are highlighted by an Australian scientist as factors defining tax behaviour. Their abbreviation formed the name of the model - BISEP. Variability of tax behaviour of tax subjects is correlated to a range of strategies of government regulation under tax compliance (figure 1), reflecting in such a manner, complex interactions between the state and the taxpayers as parties to the tax relationships (OECD, 2004).

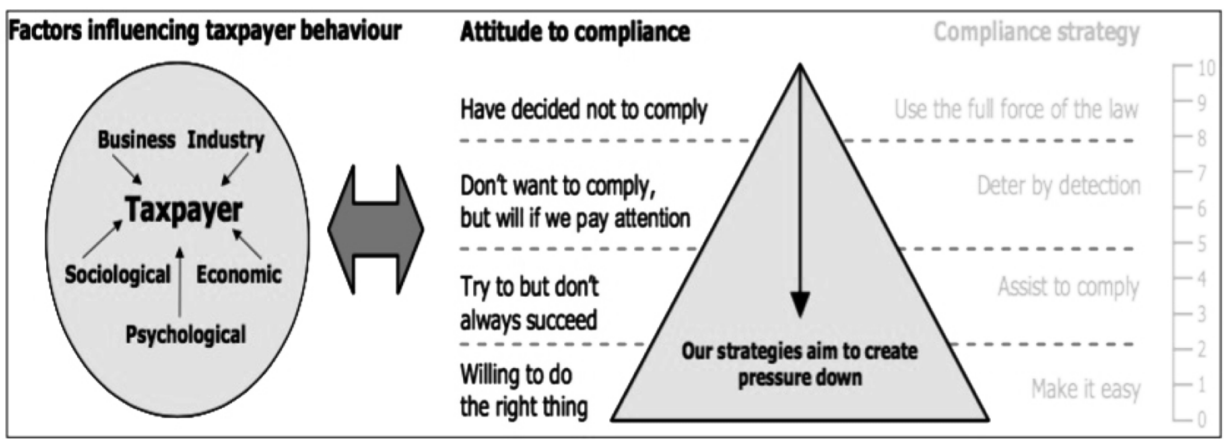

Figure 1. A model of compliance.

Source: OECD, 2004. 
Service strategy as a type of tax control strategy is based upon behavioral theory including the deterrence theory. This combination of the theoretical basis provides the opportunity to generate in tax control strategy both deterrence and other purposes, tasks, resulting from the tax behaviour factors to be considerated for the best impact of the subjects attitude to tax compliance given multifaceted specificity of human factor. Emphasis on consideration of psychological factors allows through the service strategy to form positive attitude to tax authorities, authorities with the growing number of taxpayers.

The next theoretical concept for the tax control strategy is the signal theory (signalling). According to this theory, it is the signalling of other persons' perception and not the behaviour rules that determine economic actors behaviour in tax relations (Posner, 2000). A person shall be bound by the coming signal of "acceptable social behaviour". The state represented by tax authorities or other subjects, acts as a signal source (signaling indicator), motivating the tax compliance. The signalling theory emphasizes the economic actors' opinion about the power, opportunities of tax authorities as a key factor of tax compliance. In this theory, not the control probability (as in the theory of deterrence) but the reputation of tax control power of the authorized bodies is the driving force for the tax compliance (Kotowski, Weisbach \& Zeckhauser, 2013). Tax behaviour is addressed in a dynamic system including multiple different interactions with feedback based on the presence of bilateral information asymmetry: a taxpayer being aware of his or her actual income, lacks the knowledge of real power of supervisory bodies; and tax authorities, being aware of the real power of tax control do not know the actual income of taxpayers (ibid).

The signalling theory has become basic for the credibility strategy in the state tax control. The high standing of the efficiency of tax control authorized bodies while interacting of tax authorities with economic actors, the latter assess as the state power and its representative bodies. As this theory is confirmed by experimental data of the credibility impact, being considered as "social capital", on macroeconomic indicators of individual countries (Knack \& Keefer, 1997; Zak \& Knack, 2001), the use of signals cannot be ignored while developing the strategy of the state tax control.

In summary, it can be noted that the above theoretic concepts of tax control strategies: 1) have similarities in consideration of tax compliance as a system, in which the key element is economic actors together with recording of cause-effect relationships for predictability of tax behaviour: 2) distinction from theoretic concepts is in the character of the driving force (motivational factors), in the level of conceptual system complicity; 3) while earlier theoretic concepts data competed, in modern conditions there is an understanding of necessity of a simultaneous application specifically aiming at certain categories of economic actors (Alm \& Torgler, 2011).

\section{Methodology}

This research is built upon institutional and delictual approach to the issue of tax control strategy which explains the tax compliance through relationship of relevant tax institutions (formal and informal), taking into account the whole diversity of tax compliance determinants and tax delicts.

As the key of the proposed strategy specificity is the addition to economic, psychological and social motivation of the actors of tax compliance, and also a moral motivation, then 
methodology of the study of the dependence of tax behaviour and tax moral by J. Alm $\mathrm{B}$ B. Torglerb (2006) was used as a basis. That will allow obtaining not only quantitative estimates but also a comparative characteristic.

American scientists considering the response to the question "Do you think that tax evasion whenever possible can always be justified or somewhere in between?" assess the level of tax moral, defining "tax moral" as a self-motivation of a person to pay taxes. The survey was conducted on a ten-point scale with a subsequent recoding to 4-pont scale. Graphic interpretation of the dependency model in figure 2 reflects a significant negative data correlation of 16 countries between tax moral and shadow economy level $(-0,567)$.

Econometric estimates, represented in the given article for the explanation of tax compliance strategy in Russia, have been carried out similar to this approach based on open data of surveys of the All-Russian Center for the Study of Public Opinion (VCIOM), shadow economy data of Rosstat and experts of the World Bank. VCIOM annual surveys for the years 2001-2016 cover 1600 people from 153 human settlements of 46 members of the Russian Federation (VCIOM).

The assessment of tax morale level is made according to 4-point scale (from 0 to 3), where 0 is assigned to the response "this is normal, acceptable", and 3 - "not acceptable" (Table 1).

Tax Morale and the Size of Shadow Economy

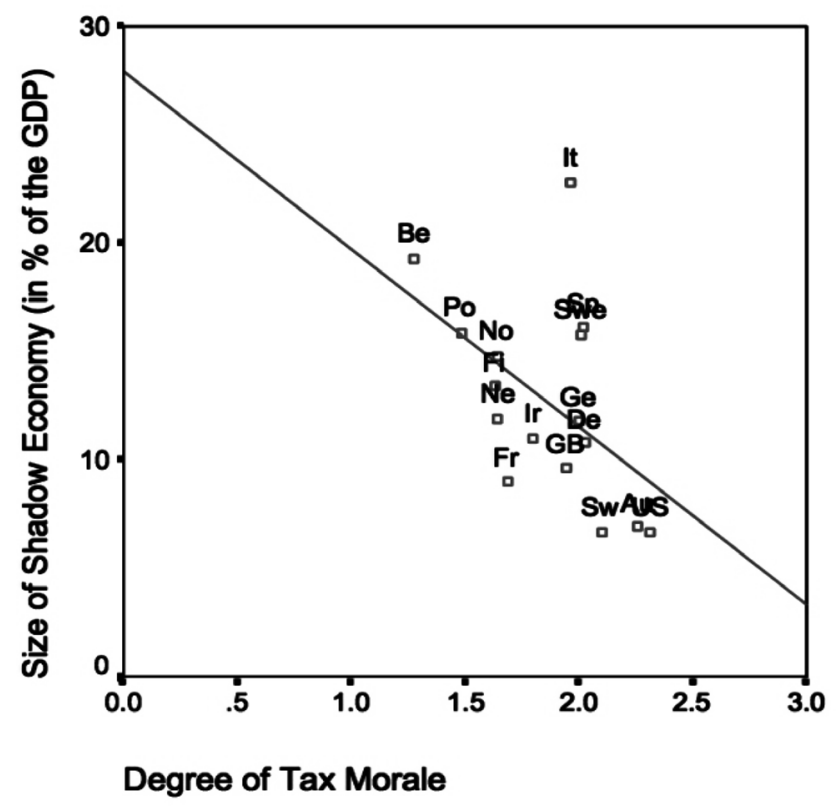

Notes: Au: Austria, Be: Belgium, De: Denmark, Fi: Finland, Fr: France, Ge: Germany, GB: Great Britain, Ir: Ireland, It: Italy, Ne: Netherlands, No: Norway, Po: Portugal, Sp: Spain, Sw: Switzerland, Swe: Sweden, US: USA.

Figure 2. Tax morale and the Size of Shadow economy.

Source: Alm, J. \& Torglerb, B., 2006. 
Table 1

Assessment of the tax morale level in RF, 2001-2016.

Distribution of responses on surveys to the expression:

It is not necessary to pay taxes to the state in full, and if there is a possibility,

You can avoid paying taxes (percentage of respondents)

\begin{tabular}{|c|c|c|c|c|c|c|c|c|c|c|}
\hline Response option & 2001 & 2002 & 2003 & 2005 & 2006 & 2007 & 2008 & 2010 & 2012 & 2016 \\
\hline Completely agree/ it is normal & 11 & 11 & 10 & 14 & 10 & 5 & 5 & 7 & 6 & 5 \\
\hline $\begin{array}{l}\text { Rather agree/ moderately } \\
\text { acceptable }\end{array}$ & 17 & 22 & 19 & 18 & 28 & 28 & 14 & 18 & 29 & 24 \\
\hline $\begin{array}{l}\text { Rather disagree/it is a matter } \\
\text { of individual choice }\end{array}$ & 36 & 36 & 29 & 32 & 16 & प & 10 & 12 & $\square$ & प \\
\hline $\begin{array}{l}\text { Completely disagree/ not } \\
\text { acceptable }\end{array}$ & 36 & 31 & 32 & 27 & 41 & 61 & 65 & 57 & 60 & 68 \\
\hline Not sure & प & $\square$ & 9 & 9 & 6 & 6 & 6 & 6 & 5 & 4 \\
\hline $\begin{array}{l}\text { Estimate (on 4-point } \\
\text { scale: } 0=\text { normal, } 3=\text { not } \\
\text { acceptable) }\end{array}$ & 1.6 & 1.5 & 1.4 & 1.3 & 1.5 & 1.8 & 2,1 & 1.9 & 1.8 & 2.0 \\
\hline in percentage & 54.0 & 49.0 & 47.0 & 43.0 & 48.5 & 61.0 & 70.0 & 63.0 & 60.0 & 67.3 \\
\hline
\end{tabular}

Source: Authors' calculations using data from VCIOM.

The ratio of the level of tax morale and shadow economy is determined in graphic interpretation (linear regression) and correlation.

\section{The results of the study}

In sight of incapacity of the classical traditional coercive strategy and its subsequently appeared alternative - service, to explain fully tax compliance issues (high level of shadow economy is preserved), in our opinion, integrated strategy is capable to provide a higher level of tax compliance through simultaneous prevention and coercion. It will allow taking into account both economic and psychological, social and moral interests of taxpayers, and explaining opportunistic behaviour in tax relations, defined by state policy in tax matters (Maiburov \& Sokolovskaya, 2012).

To date, the idea of combination of strategies is not considered an innovation. The principle of flexible regulation is built on a productive combination of conviction and sanctions (Ayres \& Braithwaite, 1992), on which the service and credibility strategies are based (Kirchler, Hoelzl \& Wahl, 2008; Alm \& Torgler, 2011). Each strategy aims at different target audience, which is reflected in figure 3 . 


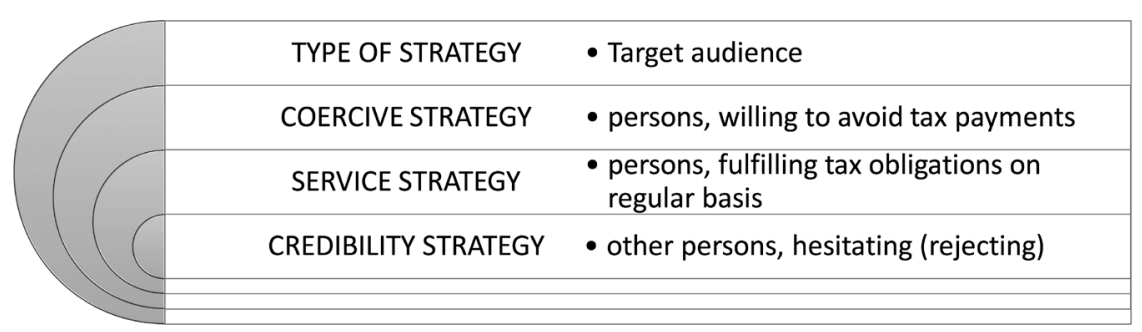

Figure 3. Target audience of separate strategies of tax control. Source: Authors.

In our opinion, the priority concepts of tax control strategy in modern conditions of development of society is an integrated strategy combining coercive strategy, the strategies of service, credibility and partnership.

Partnership in tax matters is meant in the context of the system of "interaction between different social actors, providing the reconciliation and fulfillment of the interests of these actors" (Ivanov, 2005, p. 84). Researching the phenomenon of social partnership, Ivanov S.A. underlines its dualistic nature. Partnership is a product of culture of participants' culture and at the same time, it is an instrument of its forming and developing. To exclude more productively intentional and non-intentional tax evasion, tax control strategy of the state should be based on not only credibility but also on partnership, i.e. to combine sanctions, conviction, education and cooperation. It is defined by the fact that consistent democratization of society requires an adequate reforming of main financial public relations - tax relations, not as coercive relations but as relations of credibility, partnership.

Here partnership relationships are intentionally distinguished, in view of the fact that they aim at different factors of tax behaviour (moral and social correspondently). Credibility is considered as positive but passive form of tax behaviour aiming at current status of the situation. Partnership, in our opinion, represents a higher, qualitatively different level of tax relations, which line taking into account moral, and ethical factors, define an active positive tax behaviour, which is supported by rights and duties of each party and thus motivate behaviour for a perspective common goals (Aytkhozhina, 2012). Vishnevsky V. notes that tax economic nature in democratic society is expressed more in voluntary payments for public goods, rather than forced alienation of property (Vishnevskii, 2004). The proposed integrated strategy of tax control is graphically interpreted in figure 4.

Advantages of this strategy are proved by the following arguments. The first. State control in tax matters acts as a public mechanism of impact on human behaviour to enforce them to comply with given norms of tax relations. But subjects of taxation are not identical, they represent a multifaceted element of a tax relations system, cooperate with other subjects participants of this system, are under influence of different institutions (formal and informal): tax audits, tax risks, traditions, moral, ethics etc. A specific motivational approach is required for each category of subjects, taking into account economic and non-economic aspects. The influence on tax compliance of a great number of factors is confirmed by the results of many foreign research activities. 


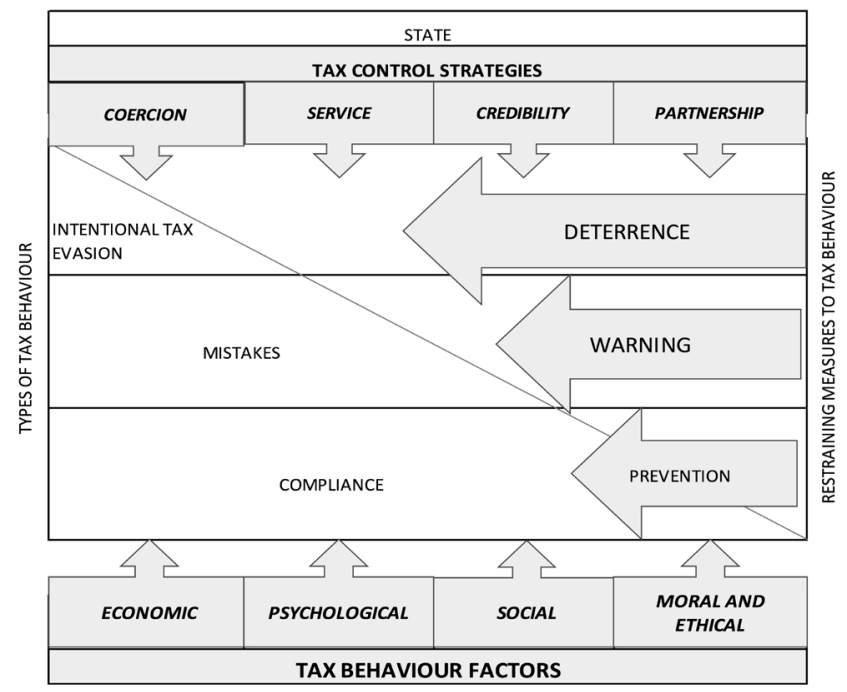

Figure 4. Integrated strategy model of tax control.

Source: Authors.

Thus, E.Kirchler, among the factors of tax compliance emphasizes psychological, social, political (Kirchler \& Braithwaite, 2007). In his graphic model tax behaviour represents the result of 2 parameters: the power of authorities and credibility of the authorities (Kirchler, Hoelzl \& Wahl, 2008). Researches from Israel experimentally proved the increase of tax compliance when introducing the International Financial Reporting Standards (Chen \& Gavious, 2015). Scientists of Great Britain have identified a higher positive influence of letters in comparison with prohibitory measures (the result is more, the expenses are less) (Hallsworth, List, Metcalfe \& Vlaev, 2017), the feedback of tax evasion and development of counselling (RamonaAnca, 2015), development of financial institutions (Blackburn, Bose \& Capasso, 2012), the correspondent ideology (Bogdanović, 2016). Researchers of the USA together with Australian ones showed the direct link between the tax compliance and culture (Tsakumis, Curatola \& Porcano, 2007), ethics (Alm \& Torgler, 2011), tax morale (Alm \& Torglerb, 2006).

The second. Tax control strategies, based on deterrence, coercion, are economically highly cost-effective, as evidenced by empirical data about state expenses for control, and hence without any regard for high impact, have low efficiency. The additional result of such strategy is high level of corruption and discontent of responsible taxpayers.

The third. Tax control models based on combination of coercion and service (is being implemented at present in the Russian Federation), are more effective, creating the perception of convenient, comfortable service within economic actors but without forming preventing instruments for tax evasion.

The fourth. Combination of coercion and warning on an equal footing requires less budgetary expenditure forming in this way a higher level of credibility for the state (Bogdanovic, 2016; Hallsworth, List, Metcalfe \& Vlaev, 2017). The potential of reducing transaction costs is large. OECD data on costs for tax administration in relation to tax revenue for the year 2013 
reflect the variation from $0,29 \%$ in Switzerland to $1,74 \%$ in Japan, in Russia this figure equals $0,81 \%$ (OECD, 2015, p. 181). In addition, the development of relations of partnership allows delegating some functions of guarantor of tax compliance to professional private actors, also reducing state costs for tax control.

The fifth. Warning and partnership as part of the strategy of tax control lower the uncertainty, strengthen stability of institutional framework, reduce administrative barriers, generating not only long-term positive results in tax compliance but also a productive basis for business, for production, exchange and distribution, defining economic growth as a whole.

Thus, in conditions of search relevance of stimuli for economic growth, democratization and information development of society, economic globalization, the represented integrated strategy of state tax control is aimed at warning and removal of widest possible range of obstacles in tax compliance. The role of moral factor in tax compliance is proved through the quantitative estimates of tax morale and interdependency of this indicator with the level of shadow economy. Similar to methodology of Alm and B. Torglerb, in this research the assessment of the level of tax morale in Russia was made on base of VCIOM surveys (Table 1 ), which dynamics is reflected in figure 5 .

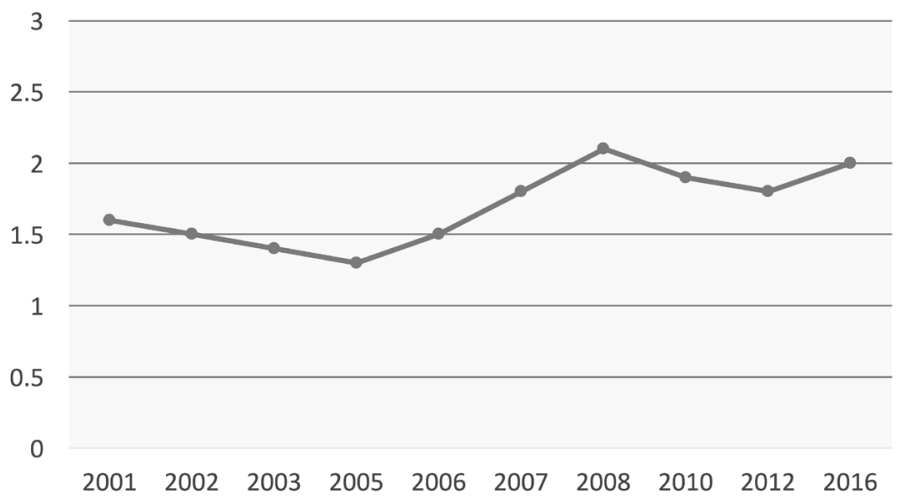

Figure 5. Dynamics of tax moral level in Russia, 2001-2016.

Source: Authors.

As can be seen, the level of tax morale in Russia for the last 15 years increased significantly, especially in the last decade.

Comparison of estimation respondents' tax morality by their activity in 2001 - 2016 (figure 6) reflects growth in tax morality level by all categories, except businessmen, having the lowest index of willingness to pay taxes. Pensioners and specialists have the highest realization of necessity to pay taxes. 


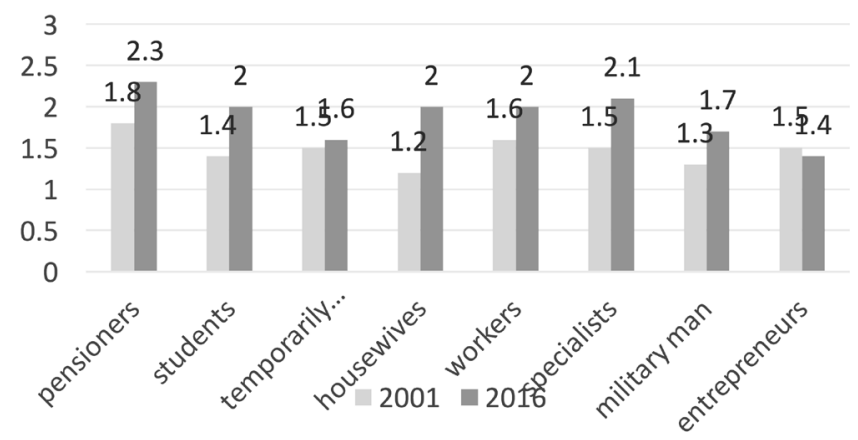

Figure 6. Level of tax morality of respondents by activity in the Russian Federation. Source: Authors.

Also data reflects that women have the higher level of tax liability (morality) then men; increasing of tax morality with aging after 45 years (figure 7 ).

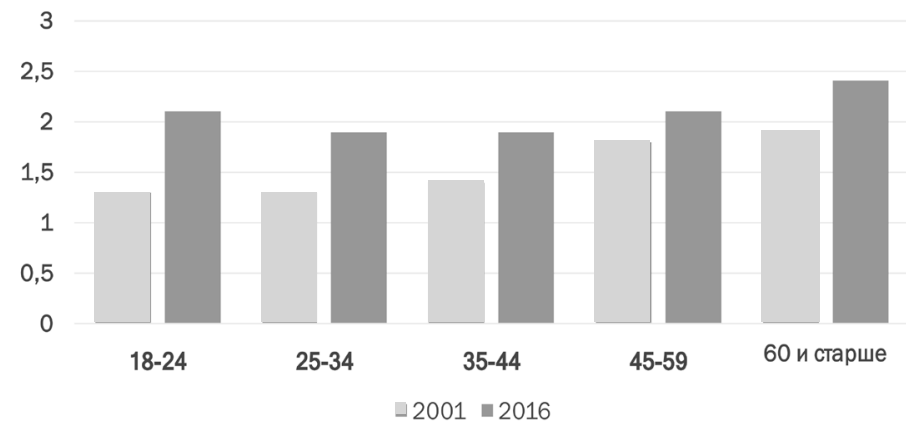

Figure 7. Level of tax morality by age in the Russian Federation. Source: Authors.

Further investigation of tax morality as a factor of tax observance reflects its essential potential. The ratio of tax morale and shadow economy level in Russia is very close to the dependency established by J. Alm and B. Torglerb (figure 8).
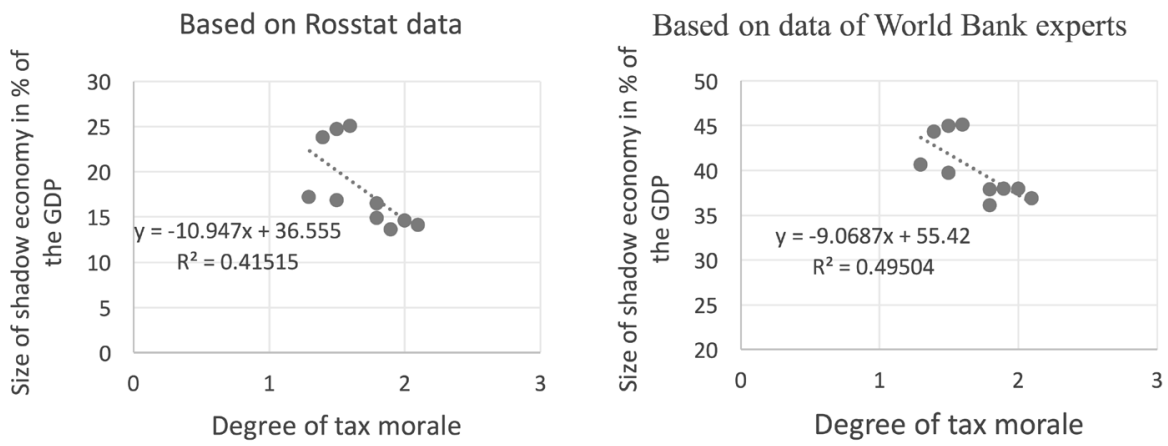

Figure 8. Ratio between tax morale and shadow economy in the Russian Federation.

Source: Authors' calculations using data from Rosstat; Schneider, 2017. 
Even a more close link is observed. The dependency reflects a considerably negative correlation $(-0,644 ;-0,703)$. According to the established dependency, increasing tax morale of 0,5 points on 4-point scale (from 0 to 3 ) corresponds the reduction of the shadow sector, according to the minimum estimate, about 4 percentage points and a degree of influence (the coefficient of determination) exceeds $40 \%$.

\section{Discussion on the results}

Under the present conditions tax administration in Russia covers 4,8 million of organizations, 3,6 million of individual entrepreneurs, more than 130 million of the other individuals. Administration of 830 taxpayers accounts for 1 tax administrator. General tendency is the increasing of the number of taxpayers, complexity of economic operations, ways of tax optimization. Annually the State incurs expenditures on tax administration realization at a rate of $0,8 \%$ from the taxes collected into the State Budget. At the same time, the level of shadow economy stays high, and the share of non-observed income, as can be seen in figure 9, grows.

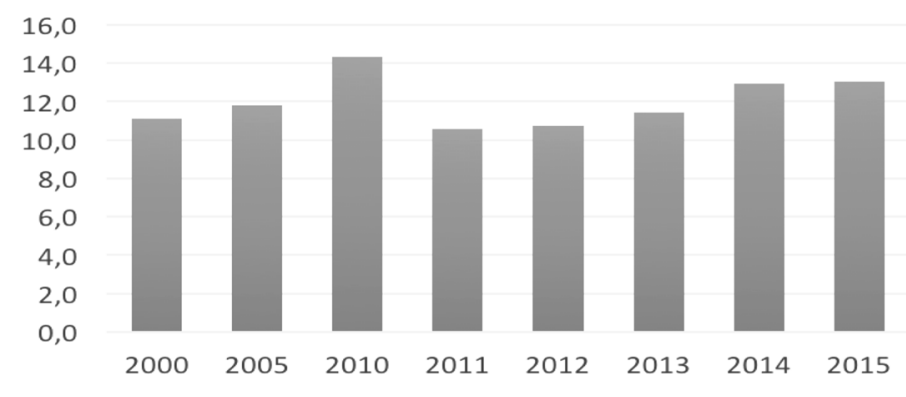

Figure 9. Non-observed income in\% to GDP of the Russian Federation, 2000-2016. Source: drawn up by authors using Rosstat data.

In this context, an important part of risk management of tax delicts is forming of social partnership relations, cooperation atmosphere and good relationships between tax authorities and taxpayers. Incorporation of instruments of mutual trust and confidence, constructive dialogue between the parties will contribute to tax compliance, forming conditions for sustainable development of society. Moreover, development potential in Russia in this direction is substantial enough. It is confirmed by data of public opinion polls (1600 persons from 46 constituent entities of the Russian Federation) (VCIOM). Regarding entrepreneurs, 39\% of the interviewed admit that a person avoiding taxation can be a patriot. And $30 \%$ of the interviewed agree with the expression "It is not necessary to pay taxes to the state in full, and if there is a possibility, you can avoid paying taxes" and consider it normal, acceptable. The fact that tax morale indicator is still behind the level of European countries and the USA even estimated for the year 2003 demonstrates significant potential (figure 10). 


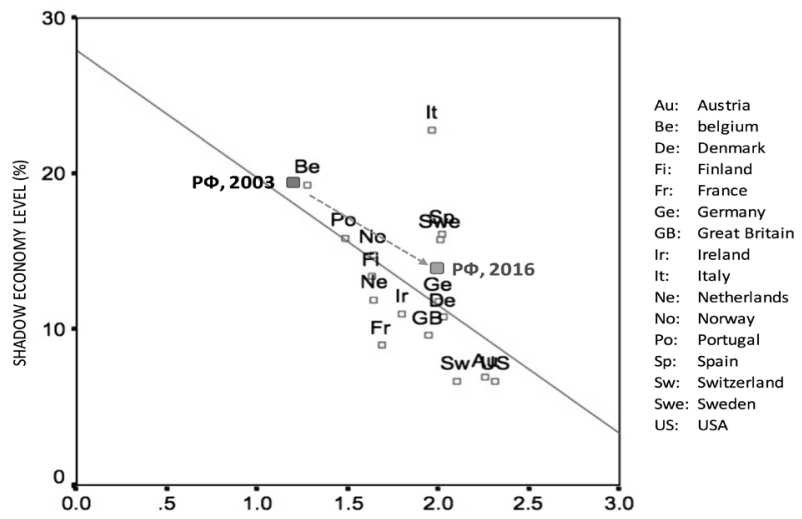

Figure 10

Dynamics of tax morale level and shadow economy in Russia in comparison with other countries. Source: drawn up by authors with inputs from Alm \& Torglerb, 2006.

The resulting econometric estimates of interrelationship between tax morale and the level of shadow economy as indicator of tax compliance, confirm that additional tools are possible and needed, in addition to traditionally coercive measures, to influence tax behaviour of taxpayers in order to promote tax morale for the growth of tax legislation compliance. Interpretation of the study results creates conditions to define the most effective instruments of preventive effect in the process of management offences in tax risks area. Indeed, legalization of only $1 \%$ GDP creates tax payments of more than 250 billion rubles (4,2 billion US dollars). This circumstance is to be considered while developing the control strategy in tax matters.

As such tools, for example, long-term certainty of taxation conditions can be used, along with incorporation of conciliation as preliminary tax treaties: strengthening the institution of pre-trial settlements of disputes; service improvement; client-oriented approach; better information and counselling (quality of tax authority service is considerably inferior to the quality of similar services of private consulting companies and specialized organizations of business support); development of tax advisors (delegating the participant status of conciliatory procedures, participant of audits); implementation of visualization tools including Data Mining method (visualization is used for information presentation and for identification of patterns, especially through visual representation easily perceived by the viewer. In tax matters, certainty and clarity are essential conditions of fairness).

The proposed measures will contribute to forming of civilized relations between tax actors and the state, establishment of partnership, business climate in tax relations, and also to prevent unintentional and partly intentional offences in tax matters.

\section{Conclusions}

The presented integrated strategy of tax control, based on partnership, has substantial benefits in comparison with alternative strategies. Benefits outweigh the expenditure for its implementation in three out of four groups of economic agents, shown in table 2. 
Table 2

Gains and losses from realization of the proposed strategy of tax control.

\begin{tabular}{|c|c|c|c|}
\hline Group & Gains & Losses & Difference \\
\hline State & $\begin{array}{l}\text { Increasing of taxpayments through the growth of the } \\
\text { collection level; reduction of expenses for control. }\end{array}$ & $\begin{array}{l}\text { Cost increases on preventive } \\
\text { measures system. }\end{array}$ & Positive \\
\hline Taxpayers & $\begin{array}{l}\text { Reduction of expenses on fines, on tax optimization, } \\
\text { on courts; increased revenue from fair competition. }\end{array}$ & $\begin{array}{l}\text { The costs of tax advisors; IT } \\
\text { software and hardware. }\end{array}$ & Positive \\
\hline Tax advisors & $\begin{array}{l}\text { Additional income from the xtension of the scope } \\
\text { (councelling, control). }\end{array}$ & - & Positive \\
\hline $\begin{array}{l}\text { Actors, } \\
\text { submitting } \\
\text { information }\end{array}$ & - & $\begin{array}{l}\text { The costs of IT software and } \\
\text { hardware. }\end{array}$ & Negative \\
\hline TOTAL & & & Positive \\
\hline
\end{tabular}

Source: Authors.

As can be seen, efficiency of the proposed strategy of control is defined by positive influence of project transformations on the state budget (reduction of the transaction costs on control at a lower cost on warning, raising tax compliance level at the account of preventive measures system), and also on taxpayers and tax advisors.

Evidence of advantages of suggested strategy of tax control is based on research results of tax morality level in Russia, estimation of potential of tax morality as a factor of tax observance. Correlation-regression analysis of data shows close link (inverse negative relationship) of tax morality and level of invisible economy (indicator of tax observance).

Decisive importance of the role of tax morality resides in the fact that forward improving of understanding of moral liability by taxpayers could potentionally essential affect to voluntary tax observance, to taxes collected in state treasury.

Summary about the role of moral factors are actual not only for Russia. Many countries of the world need to increase of budget revenue not by strengthening of tax burden, but by improving of tax observance. Also achieved results present useful information for tax organs for forming of tax policy, taking into account differentiation of tax moral level of separate population groups (by gender, age, activity etc.) for further scientific studies in the sphere of tax control planning.

\section{References}

Allingham, M. \& Sandmo, A. (1972). Income tax evasion: a theoretical analysis. Journal of Public Economics, 1 (3-4), 323 - 338. https://doi.org/10.1016/0047-2727(72)90010-2

Alm, J. \& Torgler, B. (2011). Do ethics matter? Tax compliance and morality. Journal of Business Ethics, 101 (4), 635-651. https://doi.org/10.1007/s10551-011-0761-9

Alm, J. \& Torglerb, B. (2006). Culture differences and tax morale in the United States and in Europe. Journal of Economic Psychology, 27 (2), 224 - 246. https://doi.org/10.1016/j.joep.2005.09.002

Ayres, I. \& Braithwaite, J. (1992). Responsive Regulation: Transcending the Deregulation Debate. New York: Oxford University Press. https://doi.org/10.1111/j.1744-1722.1994.tb00048.x

Aytkhozhina, G.S. (2012). Formirovanie instrumentov partnerstva v nalogovoi sfere. Vestnik Kostromskogo gosudarstvennogo universiteta im. Nekrasova, 5, 216-218.

Becker, G. (1968). Crime and punishment: an economic approach. The Economic Dimensions of Crime, 13 - 68. https://doi.org/10.1007/978-1-349-62853-7_2 
Blackburn, K., Bose, N. \& Capasso, S. (2012). Tax evasion, the underground economy and financial development. Journal of Economic Behavior \& Organization, 83 (2), 243 - 253. https://doi.org/10.1016/j.jebo.2012.05.019

Bogdanovic, M. (2016). Manipulation of human mind as dominant strategy in achieving tax compliance. Romanian Economic Business Review, Romanian-American University, 11 (1), 24-51.

Braithwaite, V. (Ed) (2003). Taxing democracy: Understanding tax avoidance and evasion. Aldershot, UK: Ashgate. Disponible en: http://valerie.braithwaite.net.au/home/tax_compliance

Braithwaite, V. \& Job, J. (2003). The theoretical base for the ATO Compliance Model. Centre for Tax System Integrity Research Note 5, Australian National University. Disponible en: http://valerie.braithwaite.net.au/home/ tax_compliance

Bruno, S. \& Frey A. (1997). A constitution for knaves crowds out civic virtues. The Economic Journal, 107 (443), 1043 - 1053. https://doi.org/10.1111/j.1468-0297.1997.tb00006.x

Chen, E. \& Gavious, I. (2015) The roles of book-tax conformity and tax enforcement in regulating tax reporting behaviour following International Financial Reporting Standards adoption. Disponible en: http://dx.doi.org/10.1111/ acfi. 12172

Dementev, V.V. (2009). Chto mi issleduem, kogda issleduem instituti? Terra Economicus, 7 (1), 13-30.

Devos, K. (2014). Factors influencing individual taxpayer compliance behaviour. Springer. https://doi.org/10.1007/97894-007-7476-6

Hallsworth, M., List, J., Metcalfe, R., \& Vlaev, I. (2017). The behavioralist as tax collector: using natural field experiments to enhance tax compliance. Journal of Public Economics, 148, 14-31. https://doi.org/10.1016/j.jpubeco.2017.02.003

Hayashi, A. (2012). The legal salience of taxation. SSRN Electronic Journal, September. https://doi.org/10.2139/ Ssrn. 2151867

Ivanov, S.A. (2005). Socialnoe partnerstvo kak fenomen civilizacii. Jurnal sociologii i socialnoi antropologii, 3 (3), 79-99.

Kapelyushnikov, R.I. (1994). Kategoriya transakcionnih izderjek. Disponible en: http://www.libertarium.ru/1_ libsb3_1-2

Kirchler, E. \& Braithwaite, V. (2007). The economic psychology of tax behaviour. Cambridge: Cambridge University Press. https://doi.org/10.1017/cbo9780511628238

Kirchler, E., Hoelzl, E. \& Wahl, I. (2008). Enforced versus voluntary tax compliance: The "slippery slope" framework. Journal of Economic Psychology, 29 (2), 210 - 225. https://doi.org/10.1016/j.joep.2007.05.004

Knack, S. \& Keefer, P. (1997). Does Social Capital Have an Economic Payoff? A Cross-Country Investigation. The Quarterly Journal of Economics, 112 (4), 1251 - 1288. https://doi.org/10.1162/003355300555475

Kotowski, M., Weisbach, D. \& Zeckhauser, R. (2013). Audits as Signals. U. CHI. L. REV., 81, 101-124. https://doi. org/10.2139/ssrn.2311417

Maiburov, I.A. \& Sokolovskaya, A.M. (2012). Problema ukloneniya ot nalogov: teoreticheskii analiz, izuchenie faktorov i posledstvii. Vestnik UrFU. Seriya: Ekonomika i upravlenie, 3, 4-15.

Manhire, J. (2016). Tax compliance as a wicked system. Florida Tax Review, 18 (6), 235 - 274. https://doi.org/10.2139/ ssrn. 2586556

OECD (2004). Compliance Risk Management: Managing and Improving Tax Compliance. Disponible en: http://www. oecd.org/tax/administration/33818656.pdf

OECD (2015). Tax Administration 2015: Comparative Information on OECD and Other Advanced and Emerging Economies. Disponible en: http://dx.doi.org/10.1787/tax_admin-2015-en

OECD (2017). Technology Tools to Tackle Tax Evasion and Tax Fraud. Disponible en: http://www.oecd.org/tax/ crime/technology-tools-to-tackle-tax- evasion-and-tax-fraud.pdf

Posner, E. (2000). Law and social norms: the case of tax compliance. VA. L. REV, 86 (8), 1781- 1819. https://doi. org/10.2307/1073829

Ramona-Anca, N. (2015) Knowledge is power. Improving tax compliance by means of boosting tax literacy. Disponible en: http://anale.steconomiceuoradea.ro/volume/2015/n1/087.pdf

Rosstat. Korrektirovka valovoi dobavlennoi stoimosti na ekonomicheskie operacii, nenablyudaemie pryamimi statisticheskimi metodami. Disponible en: http_//www.gks.ru/wps/wcm/connect/rosstat_main/rosstat/ru/statistics/ accounts/\# 
Schneider, F. (2014). The Shadow Economy in Europe, 2013. OECD Statistics Brief, 18.

Schneider, F. \& Medina, L. (2017). Shadow Economies around the World: New Results for 158 Countries over 19912015. CESifo Working Paper Series 6430, CESifo Group Munich. Disponible en: http://www.econ.jku.at/papers/2017/wp1710.pdf

Tsakumis, G., Curatola, A. \& Porcano, T. (2007). The relation between national cultural dimensions and tax evasion. Journal of International Accounting, Auditing and Taxation, 16 (2), 131 - 147. https://doi.org/10.1016/j.intaccaudtax.2007.06.004

VCIOM. Baza rezultatov oprosov rossiyan "Arhivarius". Disponible en: https://wciom.ru/database/baza_rezultatov_ oprosa_s_1992_goda/

VCIOM. Baza rezultatov oprosov rossiyan "Sputnik". Disponible en: https://wciom.ru/database/baza_rezultatov_ sputnik/

Vishnevskii, V. (2004). Uklonenie ot uplati nalogov i racionalnii vibor nalogoplatelschika. Voprosi ekonomiki, 2, 96-108. World Bank. Rating "Paying Taxes". Disponible en: http://www.doingbusiness.org/data/exploretopics/paying-taxes

Zak, P. \& Knack, S. (2001). Trust and Growth. The Economic journal, 111 (470), 295 - 321. https://doi.org/10.1111/14680297.00609 